SL. 1. A.V. PAPKov: Zgrada Josipa HRABovskoga, VINOGRADSKA CESTA 25, ZAGREB, PROČELIE, 1932.

Fig. 1 A.V. PAPKov: J. HRABOVSKI HousE,

25 VINOGRADSKA CESTA, ZAGREB, FACADE, 1932

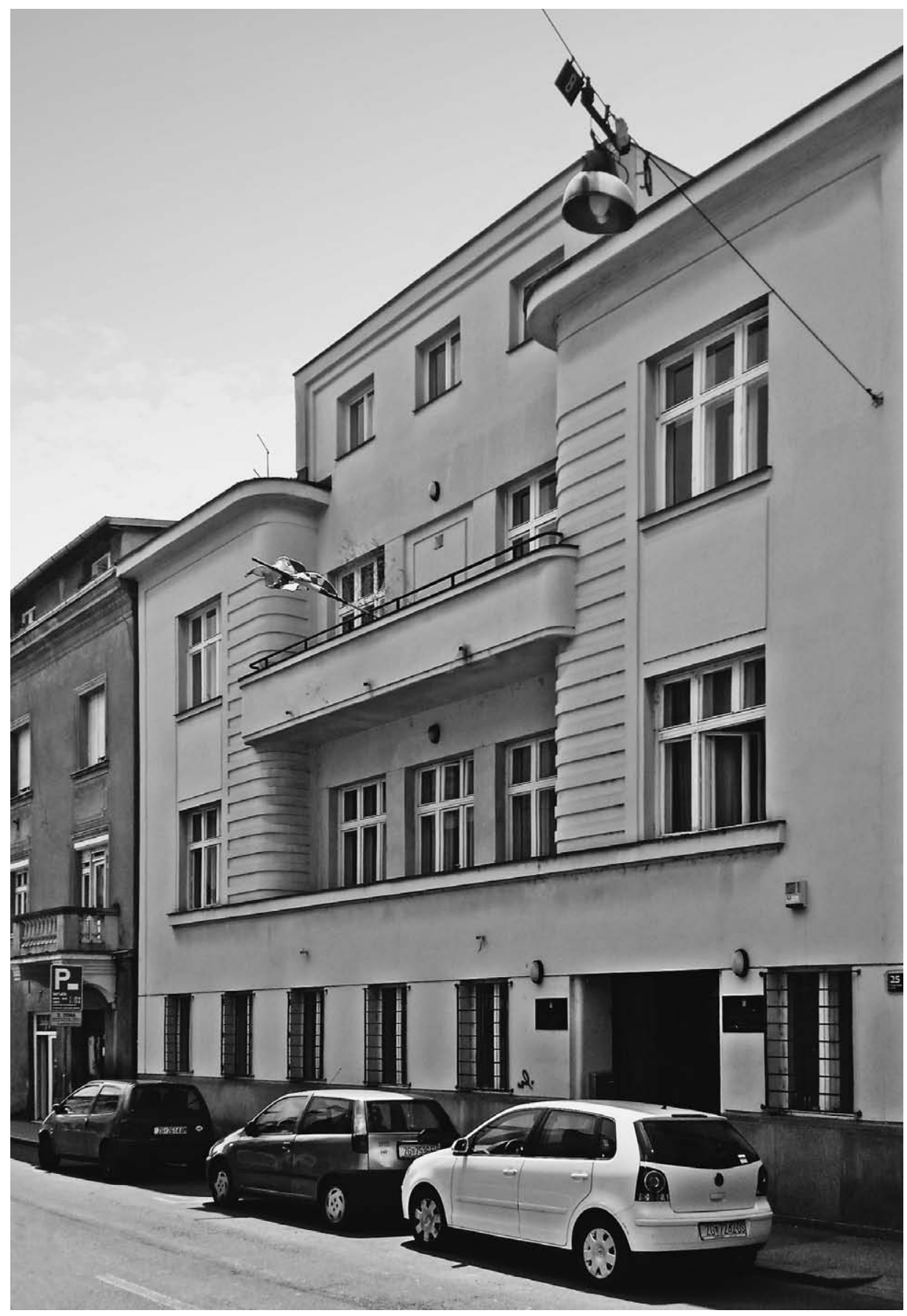




\section{Aleksandar Kadijević}

UNIVERZITET U BEOGRADU

FILOZOFSKI FAKULTET

ODELJENJE ZA ISTORIJU UMETNOSTI

SRBIJA - 11000 BEOGRAD, ČIKA LJUBINA 18-20

akadijev@f.bg.ac.rs

Pregledni ZnANSTVENI ČLANAK

https://doi.org/10.31522/p.26.2(56).8

UDK 72.035:72.036 (470:497.5) "19"

TEHNIČKE ZNANOSTI / ARHITEKTURA I URBANIZAM

2.01.04. - POVIJEST I TEORIJA ARHITEKTURE I ZAŠTITA GRADITELJSKOG NASLIJEĐA

ČLANAK PRIMLJEN / PRIHVACEN: 9. 9. 2018. / 11. 12. 2018.
UNIVERSITY OF BELGRADE

FACULTY OF PHILOSOPHY

DEPARTMENT OF ART HISTORY

SERBIA - 11000 BELGRADE, ČIKA LJUBINA 18-20

akadijev@f.bg.ac.rs

Scientific Subject Review

https://doi.org/10.31522/p.26.2(56).8

UDC 72.035:72.036 (470:497.5) "19"

TeChNical SCIEnces / ARChitecture And URban Planning

2.01.04. - HISTORY AND THEORY OF ARCHITECTURE

and Preservation of the Built Heritage

Article Received / AcCepted: 9. 9. 2018. / 11. 12. 2018.

\section{DJELATNOST RUSKIH ARHITEKATA EMIGRANATA U HRVATSKOJ I JUGOSLAVIJI (1920.-1980.)}

\section{Professional Work of RUSSIAN IMMIgRANT ARCHITECTS In CRoAtia ANd YugoslaVia (1920-1980)}

\author{
ARHITEKTI EMIGRANTI IZ RUSIJE \\ ZAGREBAČKI DIPLOMANTI ARHITEKTURE
}

$\mathrm{U}$ pregledu arhitektonske djelatnosti emigranata iz Rusije ovom se prilikom aktualizira rad graditelja iz drugih jugoslavenskih sredina u hrvatskim gradovima, kao i doprinos zagrebačkih diplomanata arhitekture ostvaren izvan granica Hrvatske. Unutar prve skupine graditelja izdvojili su se Andrej Papkov, Andrej Ševcov, Viktor Zelinski i Valerij Staševski, dok su se u drugoj afirmirali Vsevolod Tatarinov, Leonid Makšejev, Viktor Zalevski, Irina Nepokojčickaja i Fedor Wenzler.

\author{
RUSSIAN IMMIGRANT ARCHITECTS \\ ZAGREB GRADUATES OF ARCHITECTURE
}

This paper presents an overview of the professional work of two groups of Russian immigrant architects: those coming from other parts of Yugoslavia who used to work in Croatian cities (Andrej Papkov, Andrej Ševcov, Viktor Zelinski and Valerij Staševski) and those who, as Zagreb University graduates in architecture, contributed to the architectural scene outside Croatia (Vsevolod Tatarinov, Leonid Makšejev, Viktor Zalevski, Irina Nepokojčickaja and Fedor Wenzler). 


\section{UVOD}

\section{INTRODUCTION}

\section{K}

o što je u historiografiji nedavno napomenuto, arhitektonska djelatnost emigranata iz Rusije vezanih za prostor Hrvatske može se promatrati iz tri povijesna kuta: 1) kroz aktivnost projektanata koji su uglavnom živjeli i radili u Hrvatskoj, 2) analizom građevina arhitekata iz drugih jugoslavenskih sredina podignutih na hrvatskom tlu, 3) prikazom opusa zagrebačkih diplomanata arhitekture ostvarenog izvan granica Hrvatske. U prvu grupu arhitekata pripadaju ličnosti koje su ostavile značajan trag u graditeljskoj kulturi hrvatskog međuraca, a dijelom i poslijeratnoga socijalističkog razdoblja, kojih je rad krajem 2017. godine prikazan u časopisu „Prostor”. ${ }^{1}$ Unutar druge skupine graditelja, privremeno angažiranih u Hrvatskoj, također se izdvaja nekoliko produktivnih autora. Uz njihov doprinos, ovom prilikom aktualiziramo i rad arhitekata iz trece skupine koji su znanja stečena na Arhitektonskom fakultetu u Zagrebu uspješno primjenjivali izvan Hrvatske. Pregled autorskih opusa izlažemo abecednim redom.

\section{GRADITELJI DRUGE SKUPINE}

\section{SECOND GROUP OF ARCHITECTS}

Među autorima koji pripadaju drugoj skupini graditelja ističe se Andrej Vasiljevič Papkov [Андрей Васильевич Папков; Gluboje kod Kurska, 15.7.1891. - Buenos Aires, 17.4.1972.; SI. 2.]. lako vezana za četiri države i dva kon- tintenta, njegova razvedena djelatnost nije potakla vecu historiografsku pozornost. Studij započet na sanktpeterburškoj Akademiji umjetnosti (1911.-1914.) okončao je 1925. godine kao drugi ruski diplomant Arhitektonskog odseka Tehničkog fakulteta u Beogra$\mathrm{du}^{2}{ }^{2}$ Nakon što je ostvario mnogo realizacija u međuratnoj Jugoslaviji, 1951. godine preselio se u Argentinu. Iako je Papkovljev beogradski opus uglavnom historiografski valoriziran, njegova aktivnost u Hrvatskoj nije temeljito istražena. Zasad se zna da je izveo dva objekta - u Zagrebu i Lipiku, te da je dobio nagradu za natječajni projekt Banovine u Splitu.

Stambenu palaču uzidanu u gradski blok na zagrebačkoj Vinogradskoj cesti 25 (SI. 1.) od Papkova je 1932. godine naručio investitor Josip Hrabovsky, koji je održavao kontakte s ruskim emigrantima. Presjeci i nacrt njezina pročelja čuvaju se u repozitoriju Muzeja za umjetnost i obrt. ${ }^{3}$ Izgrađena na neravnoj parceli, kuca Hrabovskoga ima dva kata s mansardnim krovom, pet prozorskih osi, stupnjevane rizalite i prazno polje prvobitno namijenjeno za reljef na središnjem prozorskom nizu drugoga kata. Na sjednici gradskog odbora za pročelja Papkovljevo je odobreno 23. kolovoza 1932. godine. Lišena funkcionalističkih obilježja 'novoga građenja', njegova dvokatnica bliža je beogradskoj umjerenijoj, nego dosljednijoj zagrebačkoj recepciji internacionalnog modernizma.

Izgrađena na nagnutom terenu, blizu raskrižja dviju ulica, izvedba palače bila je složen građevni pothvat. Izvedbu je u listopadu 1932. nadziralo građevinsko poduzetništvo arhitekta Lava Kalde, koje je tijekom 1933. izvršilo izmjene prvotnoga plana. Povecan je broj prozorskih otvora u prizemlju s tri na pet, dok su tavanske prostorije pretvorene u treci kat. Simetričnost, centralizam, naglašavanje razdjelnih točaka slojevita pročelja širokog 18 metara, odijeljenog na tri vodoravne zone, cjelinu vezuju za ustaljena rješenja beogradske modernističke škole. ${ }^{4}$ Terasa drugoga kata, uz pojednostavljenu atiku na vrhu, predstavlja glavni plastički motiv pročelne kompozicije. U unutrašnjosti palače također prevladava ustaljeni sustav prostorne hijerarhije sa stubišnim traktom u središtu, uslužnim prostorijama u prizemlju (komora, kabina za dizalo, garaža, sobe za domara i voza-

1 KADIJEVIĆ, 2017.a

2 Prvi diplomant bio je Viktor Mesner, a drugi Andrej Papkov. Vidjeti: MARKOVIC, 1939: 26.

3 Na ovu atribuciju i historijske dokumente ljubazno nam je ukazala arhitektica Sandra Brajkovic iz dubrovačkog studija „Quasar”. Rijeć je o nacrtu "presjeka kroz glavnu osovinu' [MU0-044811/o4], nacrtu 'presjeka kroz ulaz', iz kojeg se vidi i rješenje izlaza u vrt iza kuce [MUO044811/03], i nacrtu 'glavnog pročelja' [MUO-044811/o2]. 


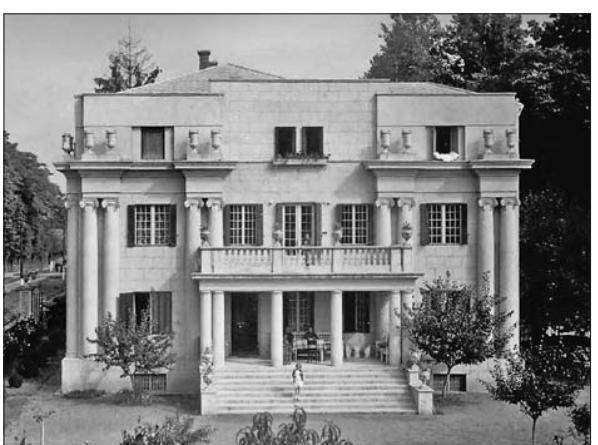

ča, perionica, centralna ložionica s ostavom za ugljen, vestibil s prolazom na desnoj strani), pravokutnom blagovaonicom flankiranom salonima na pročelju prvoga kata (SI. 6.), halom, dvjema spavacim sobama i terasom u dubini plana te cetirima spavacim sobama na drugom katu.

Određene pregradnje i prenamjene u zgradi izvršene su 1939.-1940. godine, kada je vlasništvo nad njom preuzeo zagrebački Mirovinski zavod za službenike. Tada je građevni poduzetnik Josip Anderlik proveo pregradnju terase - mansarde i pretvorio sobu na prvom katu u ured. Unatoc tim intervencijama, originalan zaobljeni vestibil Papkovljeva pročelja prema vrtu zadržao je prvobitni oblik.

Zgrada Josipa Hrabovskoga pripada među prva Papkovljeva ostvarenja nastala nakon osnutka njegova privatnoga beogradskog biroa (1932.) te ce slična kompozicijska rješenja u sljedecim godinama primijeniti diljem prijestolničke centralne zone. ${ }^{5}$ Efektno uvlačenje središnjeg dijela pročelja slijedi motiv s interpolirane višekatnice dr. Borivoja Đurića (1931.), koju je na beogradskom Zelenom vencu 10 podigao Papkovljev dugogodišnji mentor Dragiša Brašovan (1887.-1965.). ${ }^{6}$

Za razliku od uzidane dvokatnice Josipa Hrabovskoga, vila zapadnoslavonskog i beogradskog fotografa Milana Savica (1883.1954.), izgrađena od 1932. do 1935. godine u Lipiku (danas na adresi Ul. Marije Terezije 13), ističe se neoklasicističkom obradom dekorativnih pročelja (SI. 4.). Podignuta kao ljetnikovac prosvijecenog naručitelja, predstavlja arhitektonski hommage kultne beogradske vile bivšega srbijanskog ministra Đorđa Genčića, započete 1927. prema projektu Dragiše Brašovana7, u čijem je atelijeru

\footnotetext{
4 MANEVIC, 1979.; BLAGOJEVIC, 2003.

5 Milovanovic, 1994.; DurDeVIC, 2005.; Ceranic, 2007.

6 KADIJEVIC, 1990: 157

7 KADIJEVIC, MASKARELI, 2004.

8 OBAD ŠĆITAROCI, 1993. Vila je unijeta u listu kulturnih dobara RH 2005. Njezini se nacrti čvaju u Muzeju Pakrac. Dio tehničke i fotodokumentacije o vili na uvid nam je lju bazno ustupila arh. Sandra Brajkovic iz dubrovačkog studija „Quasar”.
}

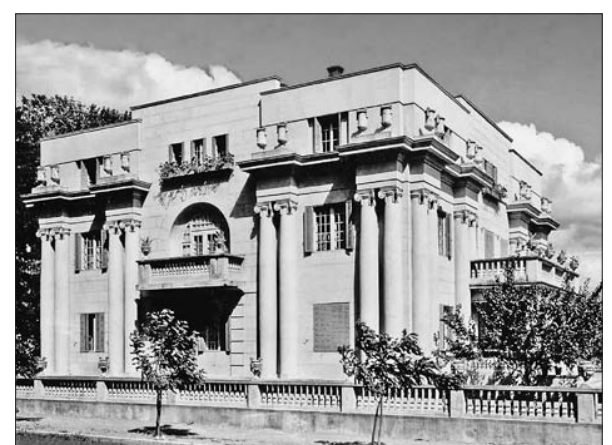

Papkov surađivao tijekom njena dovršetka 1929. godine (Sl. 5.).

Nametljiva i reprezentativna, dvokatna vila u Lipiku ima dekorativno obrađena pročelja, a stražnja joj je fasada lišena stilske dekoracije (SI. 3.). Bogatim historicističkim repertoarom vizualno se izdvojila u ambijentu lječilišnih, ugostiteljskih i rezidencijalnih zgrada. ${ }^{8}$ Vila je podrumljena, zidana opekom na betonskim temeljima. Stropna je ploča nad podrumom armiranobetonska, a ostali su stropovi drveni grednici. Stubište je prefabricirano betonsko s čeličnim traverzama. Zapadno i južno pročelje bogato su ukrašeni plastikom i projonskim stupovima, a na katu balkonima sa zidanim ogradama. Međukatni vijenac je bogato profiliran i ukrašen stiliziranim vazama. Nadozid je podignut tako da skriva krov. Ispred građevine lijepa je zidana ograda sa stiliziranim vazama i naglašenim ulazima s nadvojima na kojima su lavlje glave. Prizemlje i katovi imaju istu prostornu podjelu, s time što je piano nobile, uređen na prvom katu, izvana reprezentativniji. Imaju po pet soba, blagovaonicu, dvije kupaonice, kuhinju, ostavu i stubišni trakt.

Poput Genčičeve kuće zamišljena u formi kompaktnoga kubičnog bloka i inspirirana paladijansko-manirističkim uzorima (primjena kolosalnog reda prislonjenih jonskih udvojenih stupova i centralnih niša u obliku trijumfalnoga luka), Saviceva vila ima dodatni atički kat i terasu u visini nižeg kata udubljenoga središnjeg rizalita, kao i četiri para stupova (za razliku od dvaju na Genčicevoj kući). Njezina su pročelja šira i razvedenija u odnosu na beogradski uzor, obogacena jonskim umjesto korintskim kapitelima stupova te završnim vijencima istaknutijeg izgleda. $\mathrm{Ne}$ maju ni krovnu balustradu s koje se mogao promatrati okoliš. Dok je Genčiceva kuca s visokim suterenom i prilaznim stubama ostala stiješnjena na parceli zauzimajuci više od dopuštenih $75 \%$ raspoloživa zemljišta, Saviceva je slobodno položena u prostor, zauzimajuci tek 263 od $1653 \mathrm{~m}^{2}$ parcele.

$\mathrm{U}$ tematskom pogledu na vili je primijenjen princip analogijskog eklekticizma, pri čemu

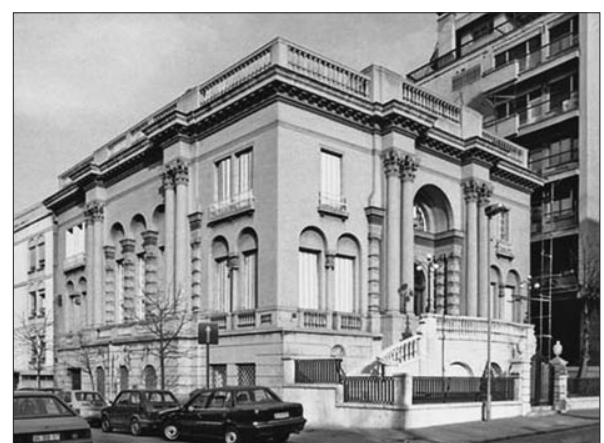

SL. 3. A.V. PAPKOV: VILA SAVIC, LIPIK, DVORIŠNO PROČELJE, 1932.-1935.

FIG. 3 A.V. PAPKOV: VILLA SAVIC, LIPIK, COURTYARD FACADE, 1932-1935

Sl. 4. A.V. Papkov: VILA Savić, MariJe TereziJe 13, LiPIK, POGLED, 1932.-1935.

Fig. 4 A.V. PAPkov: Villa Savic, 13 Marije TereziJe St., LIPIK, ELEVATION, 1932-1935

SL. 5. D. BRAŠovan: KuCA DORDA GENČICA, KRUNSKA 51, BEOGRAD, 1927.-1929.

Fig. 5 D. Brašovan: Đ. Gencic House, 51 KRunska ST., BELGRADE, 1927-1929

SL. 6. A.V. Papkov: Zgrada Josipa Hrabovskoga, VINOGRADSKA CESTA 25, ZAGREB, TLOCRT PRVOGA KATA, 1932.

FIG. 6 A.V. PAPKOV: J. HRABOVSKI HOUSE, 25 VINOGRADSKA CESTA, ZAGREB, FIRST-FLOOR PLAN, 1932

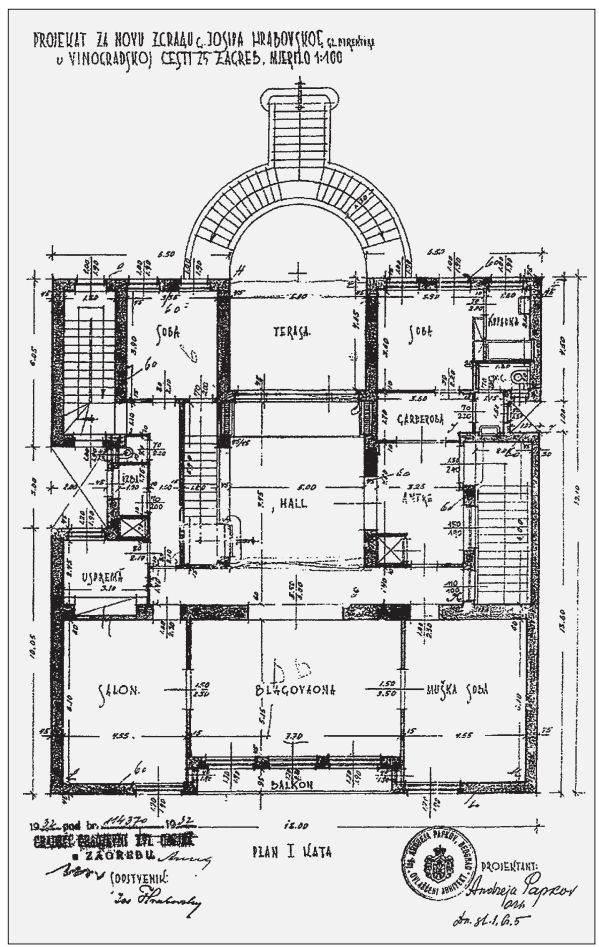




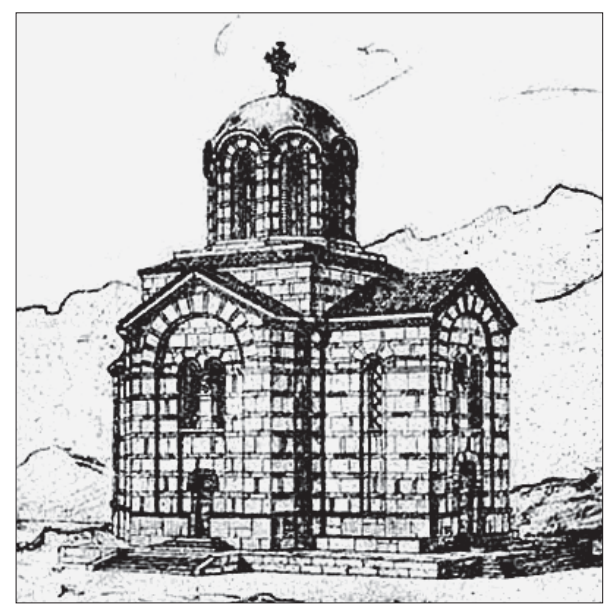

SL. 7. V.V. StAŠ́EVSKI: CRKVA SV. SPASA, CETINA, SKICA, 1937.-1940.

Fig. 7 V.V. StaŚEVSki: Church of Holy Salvation, CETINA, SKETCH, 1937-1940

Sl. 8. V.V. Staševski: CRKva sv. Spasa, Cetina, 1937.-1940.

Fig. 8 V.V. StaŚEVSki: Church of Holy Salvation, Cetina, 1937-1940

SL. 9. V.V. STAŠEVSKI FIG. 9 V.V. STAŠEVSKI

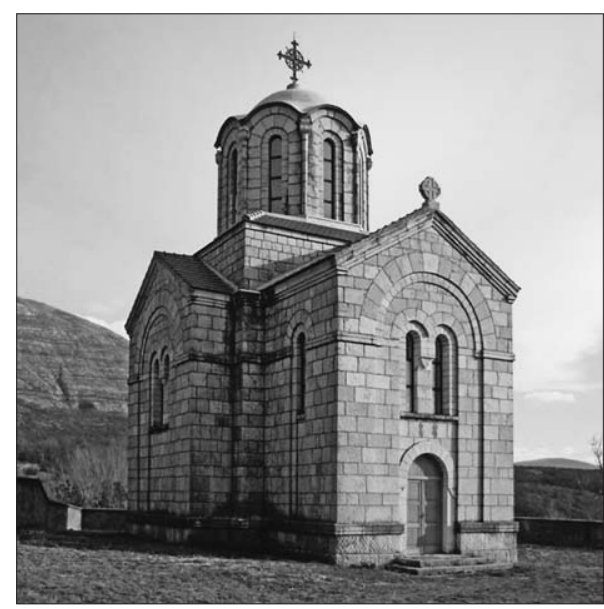

Genčićeva kuća nije doslovno oponašana. Dok je njezino ugaono pročelje bazirano na talijanskim predlošcima, dvorišno je izgrađeno u maniri engleske neorenesanse. Također je trodijelno i ima trijem sa stubama. Njegov je piano nobile istaknut razvijenom terasom. Milan Savić bio je snažno involviran u uobličavanje građevnog programa vile sa 23 prostorije. ${ }^{9}$ Prvobitno projektirana kao katnica, izvedena je sa dvama katovima. Tijekom izvedbe, uza sitne intervencije na istočnom pročelju, izmijenjeno je unutrašnje stubište dodan stražnji ulaz. Izvedbu vile s rezidencijalnom i komercijalnom namjenom proveo je pakrački graditelj Franjo Vacek.

Papkov je iz Beograda još 1930. godine sudjelovao na splitskom javnom natječaju za Idejnu skicu novih Banskih ureda, u žiriju kojeg su, pored ostalih uglednika, bili i Ivan Meštrovic i Edo Šen. Na natječaj su se odazvala čak 33 autora. Postavljen je uvjet da palača bude projektirana „u slobodnom monumentalnom stilu, ali njezin opci karakter i oblik imaju sadržavati klasičan ritam, uzimajuci u obzir kameni građevni materijal koji ce harmonizirati sa primorskim pejsažem". Prema mišljenju stručnog žirija nijedan rad nije zadovoljio uvjete natječaja, iako je među sudionicima bilo više predstavnika zagrebač ke moderne. Prva i druga nagrada nisu dodijeljene, a trecu su ravnopravno podijelili projekt „Diamant” Andreja Papkova i Velimira Gavrilovića iz Beograda te „Ad Palatium” Dujma Granica (u iznosu od po 20.000 dinara). Nakon što je natječaj zaključen bez realizacije, projekti su izloženi u Salonu Galić u Marmontovoj ulici početkom prosinca. ${ }^{10} \mathrm{Na}$ tječaj je ponovljen 1937. godine.

Građevinski inženjer iz Beograda Valerij Vladimirovič Staševski [Валерий Владимирович Сташевский; SI. 9.], koji je imao čin pukovnika ruske vojske, na inicijativu Dušana Četnika u Cetini je podigao zavjetnu jednokupolnu crkvu sv. Spasa (1937.-1940.). ${ }^{11}$ Rođen
1882. godine, Staševski je diplomirao na Visokoj nikolajevskoj vojnoj školi u Sankt Peterburgu. Diplomu je nostrificirao na Tehničkom fakultetu Univerziteta u Beogradu 1930. godine, na kojem je još od 1924. razvio plodnu projektantsku djelatnost (više od tisucu potpisanih planova), gradeći i za rusku emigrantsku zajednicu (hram sv. Trojice na Tašmajdanu i Iverska kapela na Novom groblju). Prve godine u egzilu proveo je u jugoslavenskom Ministarstvu građevina, da bi 1927. registrirao privatno projektantsko poduzece. Među njegovim se realizacijama ističu vile $u$ Činovničkoj koloniji na Vożdovcu i nekoliko stotina interpoliranih stambenih zgrada. Prema svjedočenju suvremenika Valerij je 1944. uhicen i sproveden u Sibir od strane NKVD-a [Narodni komesarijat unutrašnjih poslova SSSR-a], dok su njegovi sinovi preko Maroka otišli u SAD. Tijekom posljednja dva desetljeća njegov se opsežan beogradski opus historiografski temeljito istražuje. ${ }^{12}$

Svojim oblicima crkva u Cetini podsjeća na hramove arhitekta Momira Korunovica, podizane diljem tadašnje Kraljevine ${ }^{13}$, a izgledom kamenih ploha bliska je tradicionalnom graditeljstvu podneblja. Njezin skladno proporcioniran križni sklop (SI. 7. i 8.), istaknut snažnim pročeljnim i bočnim zabatnim zidovima, nadvišen je osmostranom kupolom koja podsjeca na srpske srednjovjekovne moravske manastire, utiskujuci cjelini potrebnu kompaktnost. Izvedbu hrama koji vizualno dominira nad izvorom rijeke proveo je graditelj Jovan Zagorac (zbog zauzetosti Staševskoga beogradskim pothvatima).

9 Iz autobiografije Milana Savica, napisane na 186 stranica, o vili Savica saznajemo sljedece: „Te poćnem praviti planove za svoju, joś kao segrt zamišljenu vilu, veliku i lijepu: ‘Vilu Savic Lipik'... Plan za vilu u Lipiku pravio je arhitekta Papkov iz Beograda prema mojoj skici i zamisli. Dotle sam ja počeo nabavljati građevni materijal unaprijed. Počeo sam dovoziti dve hiljade kubika pijeska i šodera, 320.000 komada cigle. U toku gradnje nabavio sam u Delnicama u Gorskom kotaru tri vagona građe i dasaka, te godine 1932. otpocnem u proljece sa zidanjem Vile Savic u sopstvenoj reżiji. Sa jednim preduzimačem iz Pakraca pogodio sam da mi sa mojim materijalom svrši sve zidarske i tesarske radove za 120.000 dinara, u akord. Tu je bila uraćunata i fasada od vencackog tucanog mramor kamena. (...) To je bila tamo prva građevina te vrste. Gradnja je napredovala, i u jesen 1932. godine bila je pod krovom. (...) Samo cašcavanje graditelja koštalo je koliko jedna solidna prizemna kuca. Preko zime nije se radilo, te sam tako odahnuo sa izdacima za gradnju, zato je u proljece 1933. počelo izvođenje fasade, koju domaci majstori ranije nisu radili, te sam dobavio iz Beograda cetiri specijalista fasadera Makedonca, koji su izradili stubove, kojih je bilo svega 18 komada. Ukrasnih vaza bilo je na kuci i oko kuce 48 komada, to je izradila firma Havelka i Zeleni iz Beograda. Bio sam zadovoljan. U zimsko doba i proljece 1933. g. postavljen je tišleraj, a u ljetu parketi. (...) Ispred vile bio je uređen engleski park sa srebrnim jelkama, sitnom zelenom travom, ukrasnim drvecem, niskim i kao kišobran obrezanim..." [CERANIĆ, 2008: 83]

10 Povijest projektiranja splitske Banske palače s osvrtom na natjeçaj iz 1930. vidjeti u: PIPLOVIĆ, 2008: 103-108, 413-414. 
Autor ruske kapele Voskresenja Hristova na zagrebačkom groblju Mirogoj Andrej Pavlovič Ševcov [Андрей Павлович Шевцов] rođen je 6.12.1890., a preminuo u Zagrebu 6.5.1940. godine. Nije precizno poznato gdje je studirao, ali se može pretpostaviti da je to bilo na nekoj od sanktpeterburških sveučilišnih ustanova. Početkom studenoga 1928. godine, na inicijativu viceadmirala carske vojske Fjodora Vjatkina, čelnika zagrebačke sekcije „Društva skrbi o duševnim potrebama pravoslavnih Rusa u Kraljevini SHS", prema njegovu je projektu podignuta jednokupolna crkva s obilježjima srednjovjekovne vladimirsko-suzdaljske škole. ${ }^{14} \mathrm{Na}$ zidovima u unutrašnjosti kapelice postavljene su mramorne ploče s uklesanim imenima pokopanih, kao i onih koji su veci dio života proveli u Zagrebu, ali su preminuli u inozemstvu. Skromna i nenametljiva, desetljećima se održala kao duhovni centar ruske emigracije (Sl. 10.).

Nikolaj Vasiljevič Vasiljev [Николай Васильевич Васильев; Pogorelka, 26.11.1875. Bayside, Long Island, 15.10.1958. $]^{15}$ također je napravio natječajni projekt u Hrvatskoj. Školovan i afirmiran u Ruskom Carstvu ${ }^{16}$, ostavio je dubok trag u arhitekturi njegova završnoga historijskog razdoblja (1900.-1917.). Glavna djela ostvario je u Sankt Peterburgu (džamija na Kronverskom prospektu, interpolirana stambena šesterokatnica u Ulici Stremnaja 11 i Novi pasaž na Litejnom prospektu) i Tallinnu (Njemačko pozorište i vila Luter).

Tijekom kratkotrajnoga beogradskog razdoblja emigrantskog stvaranja (svibanj 1921. veljača 1923., kada odlazi u SAD ${ }^{17}$ Vasiljev se

\footnotetext{
11 Čolović, 2011: 268-269, 293

12 ĐURDEVIĆ, 1998.-1999.; LATINČIĆ, 2011.

13 KADIJEVIC, 2012

14 PUŠKADIJA-RIBKIN, 2006: 182-183; KosıK, 2010: 374

15 LISOVSKI, GACHOT, 2011.

16 Nakon završenog Instituta civilnih inženjera (1902.)
} diplomirao je na Arhitektonskom odsjeku Akademije umjetnosti (1904.) u Sankt Peterburgu kod prof. Leontina Benue (1856.-1928.)

17 Jahontov, Prosen, 2013.

18 BAGARIC, 2011: 211, 257

19 BAGARIĆ, 2011: 211, 257

20 LEKO, 1926: 194-195

21 Nezadovoljan niskim primanjima u Kraljevini SHS usprkos kontinuitetu rada, Vasiljev se odlučio za odlazak u SAD, manje opterecene poratnim ekonomskim problemima. Tako u veljaci 1923. brodom preko Francuske odlazi u New York. Ipak, tamo se nije uspio nametnuti američkim naručiteljima pa je pretežno radio kao pomocni arhitekt vizualizator velikih projektantskih poduzeca. Umirovljen je 1953. godine.

22 CVIJIC, 2014: 51

23 JovanOVIĆ, 2006: 346

24 Crkva je vec godinama zatvorena. U novije vrijeme potpala je pod skrb Srpske pravoslavne parohije u Rijeci. nagrađenim natječajnim projektom Gradske štedionice (srpanj 1921.) na Jelačićevu trgu uspješno predstavio zagrebačkoj publici. ${ }^{18}$ Prema mišljenju žirija, sastavljenog od uglednih profesora zagrebačke Tehničke visoke škole Ede Šena i Milana Čalogovića, kao i lokalnog arhitekta Lava Kalde, uspio je osvojiti prestižnu drugu nagradu ispred pedesetak konkurenata. Buduci da prva nagrada nije dodijeljena, uz komentar da nijedan rad nije zadovoljio potrebne kriterije, Vasiljev je najbolje rangirani sudionik natječaja. Međutim, kako to često biva, u veljači 1923. godine konačna izrada nacrta i nadzor nad gradnjom nisu povjereni njemu, već iskusnom arhitektu Ignjatu Fischeru (1870.-1948.). ${ }^{19}$ Tri godine poslije njegov natječajni projekt beogradske palače Ministarstva šuma i rudnika, poljoprivrede i voda (1921.), osmišljen s obilježjima monumentalnoga imperijalnog neoklasicizma, komentiran je u zagrebačkom „Tehničkom listu" ${ }^{20}$, premda je Vasiljev tada živio u New Yorku. ${ }^{21}$

Arhitekt emigrant iz Rusije Viktor Zelinski [Виктор Зелинский; Varšava, 1900. - Zagreb, 1985.] također je ostavio autorski trag na tlu Hrvatske. Nije precizno utvrđeno mjesto njegova školovanja. Nakon dolaska iz Rusije projektirao je crkvu u Crikvenici, koje je izgradnja počela 1928. godine. Od 1934. do 1939. živio je u Niškoj Banji, a zatim se doselio u Banjaluku gdje je postavljen za vršitelja dužnosti šefa tehničkog odjela Higijenskoga zavoda. Tijekom Drugoga svjetskog rata povremeno je boravio u Zagrebu. Imao je kcer Sofiju koja je 1995. godine diplomirala na zagrebačkom Arhitektonskom fakultetu. ${ }^{22}$

$\mathrm{Na}$ inicijativu udovice bivšega ruskog poslanika (1909.-1914.) u Kraljevini Srbiji Nikolaja Hartviga - Aleksandre Pavlovne Hartvig, u Crikvenici je po nacrtima Zelinskoga podignuta pitoreskna ruska crkva posvecena sv. Nikoli (Sl. 11.). ${ }^{23}$ Nju su još 1924. godine dali izgraditi emigranti iz Rusije koji su živjeli u tom dijelu Hrvatskog primorja. lako nevelikih dimenzija, ona se po arhitektonskom i vjerskom značenju može usporediti s najznačajnijim ruskim hramovima u Jugoslaviji crkvom sv. Trojice na Tašmajdanu i Iverskom kapelom na Novom groblju u Beogradu (inž. Valerij Vladimirovič Staševski, projektant crkve u Cetini) i hramom sv. Jovana Bogoslova u Beloj Crkvi (autor Andrej Pavlovič Ševcov, projektant mirogojske ruske kapele). Ipak, ruska nacionalna komponenta na crikveničkoj je crkvi zastupljenija u detaljima (lukovičasti oblici kupole i elementi unutrašnjeg dekora), nego u ukupnom sklopu, prilagođenom primorskom podneblju. Osamdesetih godina prošloga stoljeća crkva je izvana obnovljena, ali je njezina unutrašnjost i dalje zapuštena. ${ }^{24}$

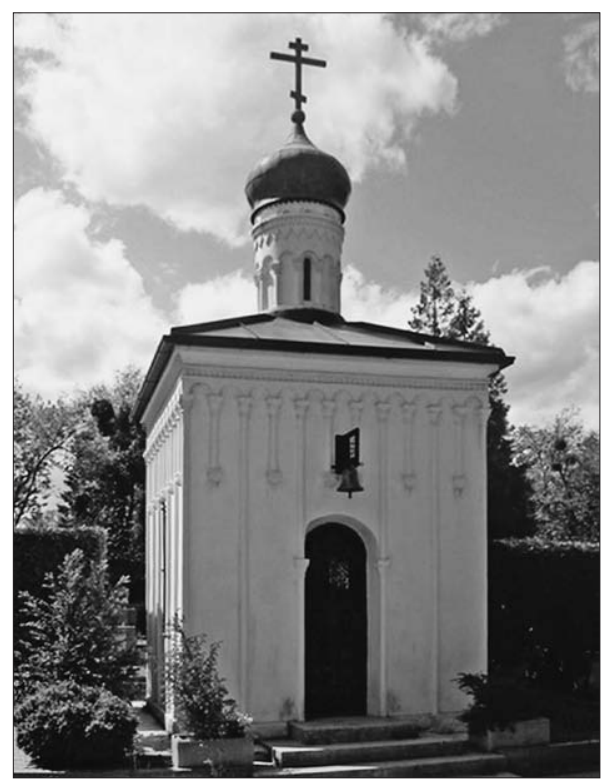

SL. 10. A.P. ŠEVCOV: VoSKRESENJSKA KAPELA NA MIRogoju, ZAgREB, 1928.

Fig. 10 A.P. Ševcov: VoskresenjSKa ChAPEL on MirogoJ, ZAGREB, 1928

SL. 11. V. ZELINSKI: CRKVA SV. NIKOLE, CRIKVENICA, 1924.-1928.

Fig. 11 V. Zelinski: St Nicholas ChURCh, CRIKVENICA, 1924-1928

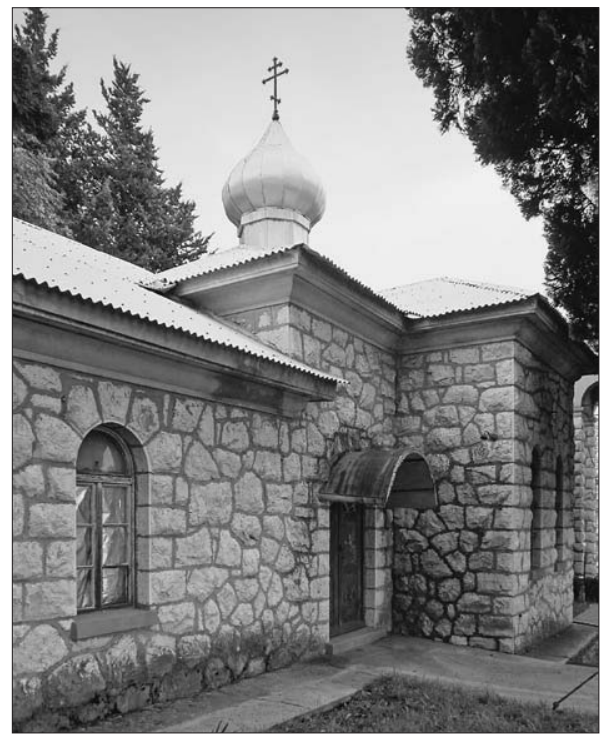




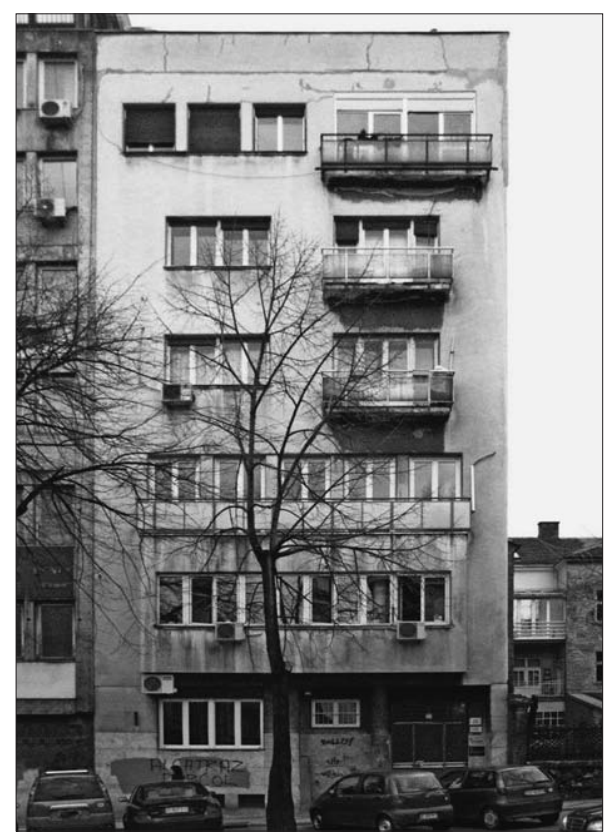

SL. 12. L.Z. MAKŠEJEV: STAMBENA ZGRADA, FRANCUSKA ULICA 22, BEOGRAD, 1938.

FIG. 12 L.Z. MAKŠEJEV: RESIDENTIAL BUILDING, 22 Francuska st., Belgrade, 1938

\section{TREĆA SKUPINA GRADITELJA}

\section{THIRD GROUP OF ARCHITECTS}

U trećoj skupini graditelja koji su se školovali u Hrvatskoj, ali su se afirmirali izvan nje, bilo je nekoliko produktivnih ličnosti. Ipak, o radu arhitekta Ivana Latiševa [Иван Латышев] sačuvano je veoma malo podataka. Rođen je 1904. godine u Harobinu. Diplomirao je na Arhitektonskom fakultetu u Zagrebu 1930. godine. Početkom četvrtoga desetljeća 20. stoljeća zaposlio se u Tehničkom odjelu Zetske banovine na Cetinju. ${ }^{25}$ Radio je kao kontraktualni arhitekt u Odsjeku za arhitektonske i elektrostrojarske poslove, zajedno $\mathrm{s}$ arh. Lavom Plahovom. Osim što je nadzirao izvedbu novih upravnih palača, 1931. je projektirao tipske osnovne škole i kotarska poglavarstva s arh. Petrom Vukoticem. Zatim je premješten u Tehnički odjel Primorske banovine u Splitu (1935.). Godine 1950. preko Budimpešte odlazi u SSSR - prvo u Taškent, a zatim u Lenjingrad, gdje je također radio. ${ }^{26}$

Više podataka sačuvano je o djelatnosti diplomanta arhitekture Leonida Zaharoviča Makšejeva [Леонид Захарович Макшеев, Sankt Peterburg 10. ožujka 1897. - ?]. Zbog prejake konkurencije u Zagrebu, po svršetku studija 1925. uputio se u Beograd, gdje se uspio stvaralački nametnuti. ${ }^{27}$ Pojedine projekte izveo je sa sunarodnjacima Valerijem Staševskim i Georgijem Bilinskim. U trecem desetljecu 20. stoljeca gradio je u maniri akademskog historicizma, da bi se u četvrtom priključio krugu modernista. Prema zapažanju U. Martinovića, Makšejev je zdušno prihvatio postulate moderne arhitekture i „sa nekoliko objekata afirmisao kao vrstan projektant”. ${ }^{28}$ Bavio se i slikarstvom. Prema sjecanju arh. Jeremejeva - Makšejev je stanovao u Ulici Molerovoj 6o. Živio je sa suprugom Anastasijom, također emigranticom. Iz arhivske građe saznajemo da je u Beogradu promijenio nekoliko adresa. Radio je kao samostalni ovlašteni projektant. Građa o njegovu djelu pretežno se nalazi u Istorijskom arhivu Beograda. Autor je i nerealiziranog projekta za crkvu u Sipicu, zamišljenu u moderniziranom srpsko-bizantskom stilu (sačuvan u Planoteci beogradskog Muzeja nauke i tehnike). Ipak, najznačajnija ostvarenja ovoga, nedovoljno proučenog graditelja jesu tri stambena objekta izvedena tijekom cetvrtoga desetljeća 20. stoljeća u središtu Beograda. To su zgrade u Ulici Francuskoj 16a i 22 te Knez Mihailovoj 25.

U Francuskoj ulici 22 Makšejev je 1938. godine sagradio kompaktnu stambenu peterokatnicu, za koju je sljedeće godine dobio nagradu za najljepše pročelje (SI. 12.). Izvedena u funkcionalističkom duhu, bliža je zagrebačkoj negoli beogradskoj recepciji internacionalno- ga modernizma (zbog upadljive suzdržanosti u likovnoj obradi površina). Nenametljivu i ogoljenu, tipično modernističku pravokutnu shemu uskoga pročelja, Makšejev je oživio različito raspoređenim katnim otvorima i nejednakim balkonskim širinama. Asimetrija je osobito naglašena u prizemlju zgrade postavljanjem ulaza na desnoj, stuba u sredini (karakterističan motiv beogradskog modernizma) i prozora na lijevoj strani pročelja.

Ekspresivnija, ali manje harmonična kompozicija pročelja ostvarena je u Francuskoj ulici 16a. Na toj masivnoj razvedenoj zgradi, s prodavaonicom u ugaonom dijelu prizemlja, iskazano je zavidno umijece u rješavanju tlocrta prilagođenog nepravilnu nagnutom terenu. Objekt se sastoji od dva trakta oblikovana nalik latiničnom slovu 'L', s time što je bočni trakt skošen. Nenaglašena asimetrija i blagi kontrasti horizontala i vertikala (karakteristični za beogradski modernizam) daju posebnu draž vanjskoj kompoziciji. S druge strane, slobodni i neusiljeni tlocrti stanova pokazuju samosvojan, netipski pristup arh. Makšejeva. Zgrada trgovca Safikjurdlija Mahmuda u Ulici Knez Mihailovoj 25 također je dovršena 1939. kao interpolirana peterokatnica trgovačke i stambeno-poslovne namjene. Jedini motiv koji narušava ravnotežu elemenata njena pročelja jest balkon postavljen u središte četvrtoga kata. Danas je u njoj hotel „Prince Hall Pallace”. Velik broj realizacija i nagrada za najljepše pročelje 1939. godine svjedoče da je arhitekt Makšejev prije Drugoga svjetskog rata bio na stvaralačkom vrhuncu. O njegovoj sudbini i stručnim rezultatima u sljedecem razdoblju zasad nema relevantnih podataka.

Irina Nepokojčickaja [Ирина Непокојчицкаja, Kuzbekova, 1909. - Sremska Mitrovica, 1948.], slikarica i arhitektica (SI. 15.), diplomirala je 1937. godine na zagrebačkom Arhitektonskom fakultetu. Kao dijete iz Poltavske gubernije, s jedanaest je godina s roditeljima izbjegla u Kraljevinu SHS. Gimnaziju je završila 1928. u Kikindi. Nakon neuspjelog upisa na studij slikarstva prijavila se na studij arhitekture. Po svršetku studija 1938. dolazi u Sremsku Mitrovicu, gdje se zapošljava kao arhitektonska crtačica u Hidrotehničkom odjelu opcine. Poslije rata prelazi u lokalni Građevinsko-tehnički odjel pri Odsjeku za naselja i zgrade, gdje ostvaruje značajne realizacije: pet vecih spomenika crvenoarmejcima poginulim prilikom oslobađanja grada (ističe se socrealistički spomenik „Narodnim heroji-

\footnotetext{
25 LATINČIĆ, 2015: 152

26 KoSIK, 2010: 364

27 Milovanovic, 2004.a, 2004.b, 2004.c

28 MARTINOVIC, 1974: 69

29 D.D., 2017.

30 PUŠKADIJA-RIBKIN, 2006: 118
} 

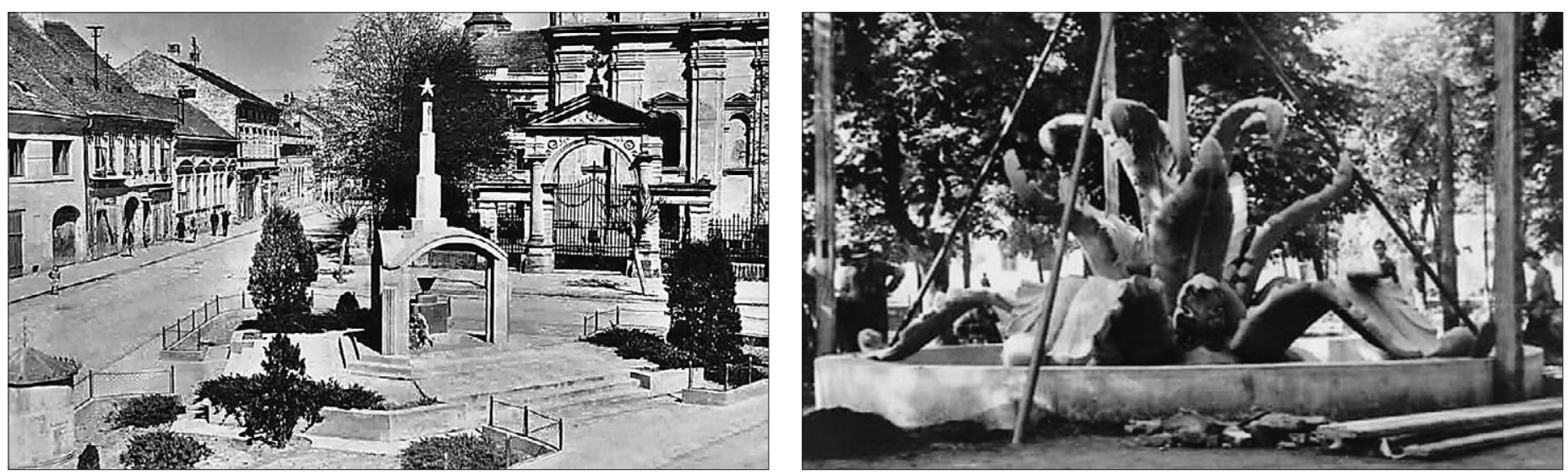

ma" na Trgu sv. Stefana, postavljen u siječnju 1946., uklonjen 1956.; Sl. 13.), uređenje ruiniranoga gradskog parka i izgradnjom impozantnoga vodoskoka „Oslobođenje” (poznatiji kao"Kameni cvijet”; SI. 14.) te uređenjem pionirskog igrališta s pozornicom za glazbu. Izvršila je i adaptaciju historicističkoga Srpskog doma osposobivši ga za kazališne predstave i glazbene priredbe. Projektirala je i izvela spomenike žrtvama fašizma na pravoslavnom groblju u Sremskoj Mitrovici, kao i mauzoleje trojici narodnih heroja Srijema. Sudjelovala je u osnivanju Muzeja istočnocrkvene umjetnosti. Nakon smrti 1948. godine pokopana je na staromu pravoslavnom groblju. ${ }^{29}$

Arhitekt Leonid Tihonovič Tarasov [Леонид Тихоно́вич Тарасов] rođen je 1899. godine u Benderi u Besarabiji. Studij arhitekture završio je u Zagrebu 1926. godine..$^{30} \mathrm{U}$ Beogradu je bio prijavljen od 1928. do 1950. godine, kada odlazi u Italiju, a potom u Venezuelu. ${ }^{31}$ Kao arhitekt Državnih monopola od 1932. godine imao je vilu u činovničkom naselju na Voždovcu. Spomenut je i na nepubliciranom popisu ruskih graditelja u Jugoslaviji, koji je sredinom četvrtog desetljeca 20. stoljeca sastavio arh. Georgije Jeremejev. U Caracasu se, osim arhitekturom, bavio i slikarstvom. ${ }^{32}$

Vsevolod Aleksandrovič Tatarinov [Всеволод Александрович Татаринов] prvi je svršeni ruski diplomant zagrebačke Tehničke visoke škole (1925.). Nije utvrđeno točno mjesto njegova rođenja i nižeg školovanja, kao i vrijeme dolaska u Kraljevinu SHS. Budući da se nije uspio uključiti u hrvatske stručne krugove, otišao je u Niš, gdje je potaknuo modernizaciju lokalnoga građevnog fonda kao ravnatelj Tehničkog odjela Banske uprave. ${ }^{33}$

\footnotetext{
31 LATINČIĆ, 2015: 156

32 KoSIK, 2010: 346

33 KADIJEVIC, 1998

34 KEKOVIĆ, ČEMERIKIC, 2006: 183-185

35 ĆANOVIC, 2018.
}

Priključio se brojnoj koloniji ruskih emigranata koja je tijekom međuraca izgrađivala jugoistočnu Srbiju. Na popisu ruskih arhitekata u Jugoslaviji, koji je sredinom četvrtog desetljeća 20. stoljeća sastavio arhitekt Georgij Jeremejev, pokraj imena Tatarinova, umjesto pune adrese, kratko je zapisano „Niš”. Upamcen je kao autor monumentalne zgrade Banovinskog kazališta (1937.), Banovinske stambene zgrade u Ulici Ćirila i Metodija 1 (1938.) i zgrade Trgovačke akademije (1940.), sve u Nišu. ${ }^{34}$

Glavno djelo Tatarinova - Banovinsko kazalište (SI. 16.) izgrađeno je na Sinđelicevu trgu na inicijativu bana Moravske Banovine Marka Novakovica. ${ }^{35}$ Građevinski odbor opcine prihvatio je projekt 21. svibnja 1937., a prva je predstava odigrana 1. siječnja 1939. godine. Uz beogradsko Narodno kazalište iz 1867., to je bila druga građevina tog tipa u Srbiji. Izgradnja je koštala 3.500.00o tadašnjih dinara. Riječ je o masivnoj građevini dinamične, razvedene siluete, $s$ nepravilnim tlocrtom, lepezasto raščlanjenim pročeljem i amfiteatralnom kazališnom salom sa 687 sjedala (od čega 24 u ložama). Glavno pročelje akcentirano je monumentalnim ulaznim dijelom, s isturenim trijemom u prizemlju i impozantnim stubištem. Uglovno pročelje efektno je zaobljeno i flankirano masivnim kubičnim blokovima. Polożaj zgrade utvrđen je kaskadnim pomicanjem masa prema središtu parcele. Stil je modernistički (s elementima art decoa), prilagođen kraju četvrtoga desetljeća 20. stoljeca, kada je monumentalnim ogoljenim formama podupiran autoritet državnih struktura (Sl. 17.). Pokretna pozornica $(14 \times 10 \mathrm{~m})$ izvedena je po projektu inž. Velimira Jovanovića, tehničkog ravnatelja Narodnog pozorišta u Beogradu, i to po principima tadašnje najsuvremenije pozornične tehnike. Poslije Drugoga svjetskog rata Tatarinov je angažiran u izgradnji centra Prištine koja je tada imala oko 17.000 stanovnika. Sagradio je jednokatno kino „Omladina” (1947.-1949.), Dom kulture (danas Narodno pozorište), Okružni
SL. 13. I. NEPOKOJČICKAJA: SPOMENIK „NARODNIM herojima”, Trg SVetog Stefana, SREmSka Mitrovica, 1946.

Fig. 13 I. NEPOKOJĊICKAJA: MONUMENT TO "NATIONAL heroes", Trg Svetog Stefana, Sremska Mitrovica, 1946

SL. 14. I. NEPOKOJČICKAJA: FONTANA „KAMENI CVIJET”, GRADSKI PARK, SREMSKA MITROVICA, 1945.

FIG. 14 I. NEPOKOJĆICKAJA: FOUNTAIN "STONE FLOWER", CITY PARK, SREMSKA MITROVICA, 1945

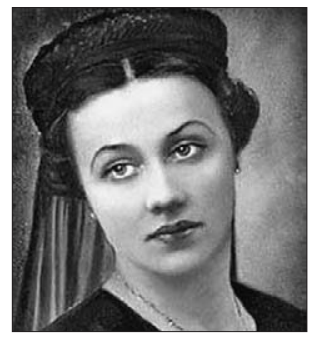

SL. 15. I. NEPOKOJČICKAJA FIG. 15 I. NEPOKOJĊICKAJA 


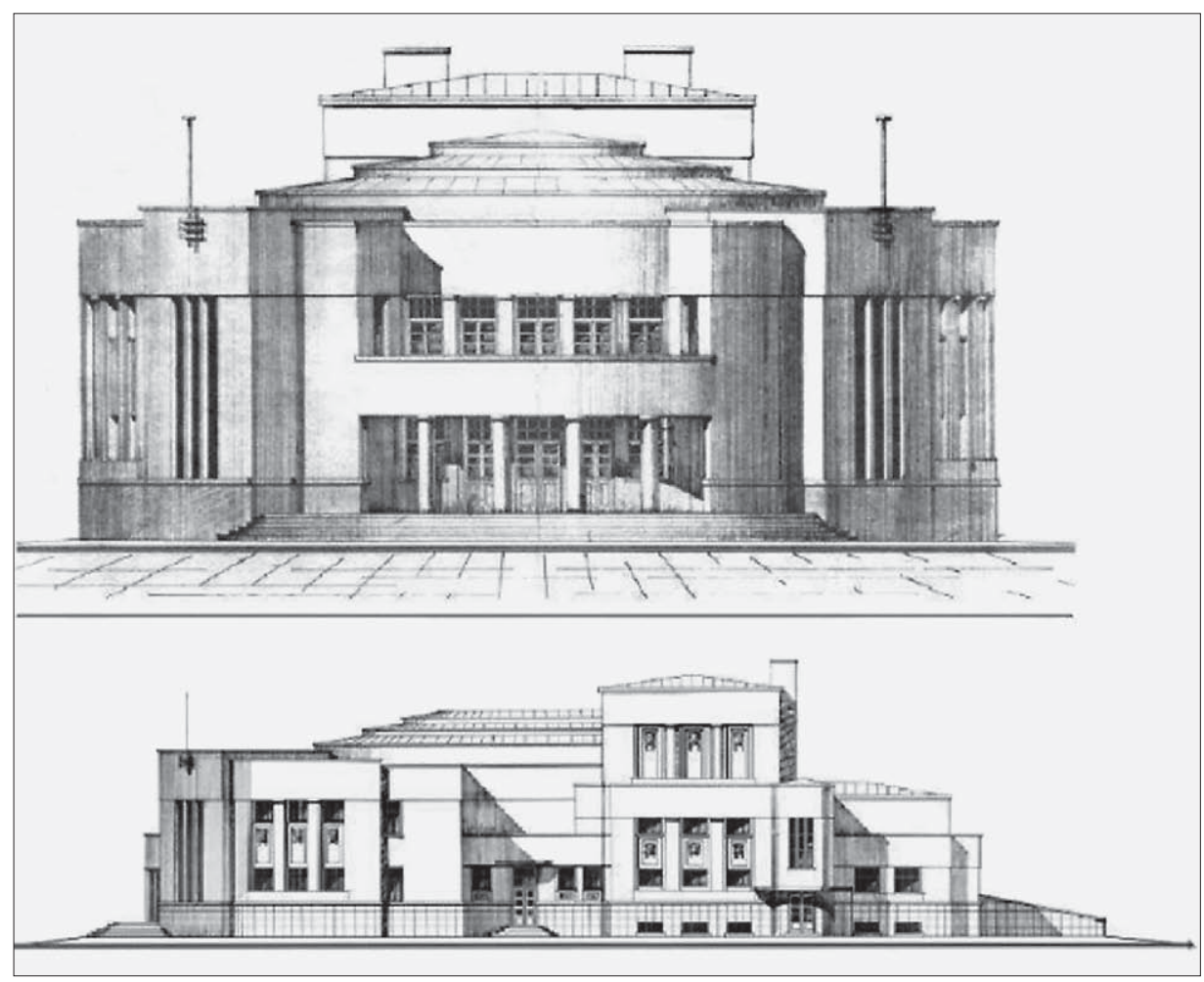

SL. 16. V.A.TATARINOV: BANOVINSKO KAZALIŠTE, SINDELICEV TRG, NIŠ, IZVEDBENI NACRTI, 1938.-1939. FIG. 16 V.A. TATARINOV: THEATRE OF BANOVINA SINDELICEV TRG, NIŚ, WORKING DRAWINGS, 1938-1939 sud iz 1947.-1949. godine (sa suradnicima), Opštinu (1948.-1949.) - sve u maniri pojednostavljenoga modernističkog monumentalizma podređenog ideologiji aktualnog socrealizma. ${ }^{36}$ Ovim podatcima zaokružuju se dosadašnja saznanja o radu arhitekta Tatarinova.

Arhitekt Nikolaj Dimitrijevič Volkov [Николай Димитриевич Волков] diplomirao je 1927. na Arhitektonskom fakultetu u Zagrebu. Pripada grupi ruskih emigranata koja je živjela i radila u Prištini. S arh. Borisom Pozdnjakovom sagradio je hotel „Kosovski božur” (1954.) u duhu internacionalnog modernizma. ${ }^{37}$ Surađivao je u projektiranju nekoliko administrativnih i stambenih objekata. Autor je i prvoga teniskog stadiona na Kosovu. ${ }^{38}$

Arhitekt Mihail Evgenijevič Vorobjov [Mn хаил Евгеньевич Воробьёв] rođen je u Moskvi 1904. godine. ${ }^{39}$ Diplomirao je arhitekturu u Zagrebu 1932. godine. Kao zavičajnu općinu u Jugoslaviji prijavio je Sarajevo. U Beograd je došao sredinom tridesetih godina 20. stoljeća iz Šapca. Ostali podatci o njegovu životu i radu zasad nisu poznati.

Fedor Wenzler (Beograd, 12. prosinac 1925. - Zagreb, 23. siječanj 2008.) odrastao je u Beogradu kao pripadnik druge generacije emigranata iz Rusije. Studij arhitekture završio je u Zagrebu $1952 .^{4^{\circ}}$, gdje je i doktorirao 1979. godine s temom „Kompleksna valorizacija prostora kao polazna osnova planiranja rekreativnih funkcija”. Radio je vrlo uspješno u Makedoniji (natječajni projekt centra Tetova, s I. Golicem, treća nagrada; natječajni projekt obnove Skoplja 1965., s Radovanom Miščevicem, prva nagrada)..$^{41}$ Pripremio je i generalni plan Devđelije, Krive Palanke; uređivao centar Kumanova i drugih mjesta. ${ }^{42}$ Koautor je mnogobrojnih prostornih planova (Prostorni plan Hrvatske, 1974.) i generalnih urbanističkih planova (Krapina, 1960.; Zabok, 1961.), te projekta za sportsko-rekreacijski centar Jarun u Zagrebu, 1961.-1987. Bavio se publicistikom, komentirajuci natječaje i ostale stručne događaje. Njegova supruga Mira Halambek Wenzler bila je pejsažna arhitektica. ${ }^{3}$

Arhitekt Viktor Zalevski [Виктор Залевский] rođen je u Hersonu 1902. godine. Diplomirao je na Arhitektonskom fakultetu u Zagrebu 1927. godine. Pripada grupi ruskih emigranata koja je aktivno djelovala u Makedoniji i na Kosovu kao dijelovima Vardarske, Moravske i Zetske Banovine. ${ }^{44}$ Još prije diplomiranja zaposlio se u Skoplju kao kontraktualni inženjer Građevinske direkcije, nadležne i za Kosovo. Od 1927. radi u Prištini kao općinski inženjer - arhitekt. Među njegovim realizacijama u tom se razdoblju izdvaja rekonstrukcija i adaptacija kuce Hadži Vitkovica u Ulici Kneza Arsena. Postojeća jednokatna građevina u osmansko-balkanskom stilu, koju je Hadži Vitkovic kupio od Turaka, Zalevski je prilagodio potrebama suvremenoga stanovanja. Od 1928. do 1930. Zalevski radi u Sarajevu kao arhitekt Tehničkog odjeljenja Drinske Banovine. U listopadu 1932. prelazi u Tehnički odjel Zetske Banovine na Cetinju. Osim što je nadzirao izvedbu državnih palača prema tuđim nacrtima, projektirao je Državnu gimnaziju u Kolašinu (s arh. Petrom Vukoticem; 1933., završena 1936.). Projektirao je i Carinarnicu u Herceg Novom (1933.), kao i Sokolski dom na Cetinju (1934.). Početkom 1935. premješten je u Tehnički odjeljak pri kotarskom poglavarstvu Cetinje, u kojem ostaje do 1940. godine. Iz tog razdoblja potječe i projekt osnovne škole u Sozini (1936.), koji mu se također pripisuje.

\footnotetext{
36 KADIJEVIC, 2017.b: 346

37 KADIJEVIC, 2017.b: 346

38 KoSIK, 2010: 378

39 LATINČIĆ, 2015: 149

$40 * \star *$ 2000: 315; KONSTANTINOSKI, 2001: 136-137; KOSIK, 2010: 377

41 IVANOVSKa DeSKova, Deskov, IVANOVSKI, 2018: 21

42 KOSIK, 2010: 377

43 KONSTANTINOSKI, 2001: 138-139

44 KosıK, 2010: 364

45 U skupljanju dokumentacije i literature za ovaj prilog pomoglo mi je nekoliko kolega kojima izražavam iskrenu zahvalnost: dr. Zlatku Karaču, arh. Sandri Brajkovic, Milošu Jurišicu, dr. Ljiljani Dobrovšak, Stanislavu Živkovu, arh. Milanu P. Milovanovicu, Aleksandri Ilijevski, dr. Viktoru Kosiku, dr. Milanu Prosenu, mr. Bojanu Kovačevicu, Ljiljani Papalagi i mr. Nebojši Anteševicu.
} 


\section{EPILOG}

\section{EPILOGUE}

Istraživanje uloge emigrantskih arhitekata iz Rusije u izgradnji Hrvatske trebalo bi institucionalno razviti i faktografski upotpuniti. Osim popunjavanja praznina u biografijama prikazanih autora, pozornost bi trebalo usmjeriti i na zagrebačke diplomante koji ovim istraživanjem nisu obuhvaćeni jer za to nije bilo dostupnih podataka: Leonida Konstantinoviča Astafjeva, Vsevoloda Lavrova (diplomirali 1926.), Aleksandra Turniševa (1927.), Konstantina Ostrovskoga (1934.), Vječeslava Burlakova, Evgenija Ivanova (1936.), Dimitrija Pograničnija, Konstantina Zapasova (1937.), Mihaila Hlopina (1938.), Mihajla Sosjeviča, Aleksandra Sišlova (1939.), Nikolaja Martinova, Jelenu Nikoljski Kottos (1946.), Anatolija Kirjakova (1949.) i Vladimira Zaharoviča. Isto vrijedi i za studente emigrante iz Rusije koji školovanje nisu okončali kao diplomanti. Evidentiranje ruskih arhitekata angažiranih $u$ opcinskim službama diljem Hrvatske također predstavlja važnu etapu u rekonstrukciji njihova civilizacijskog doprinosa. ${ }^{45}$

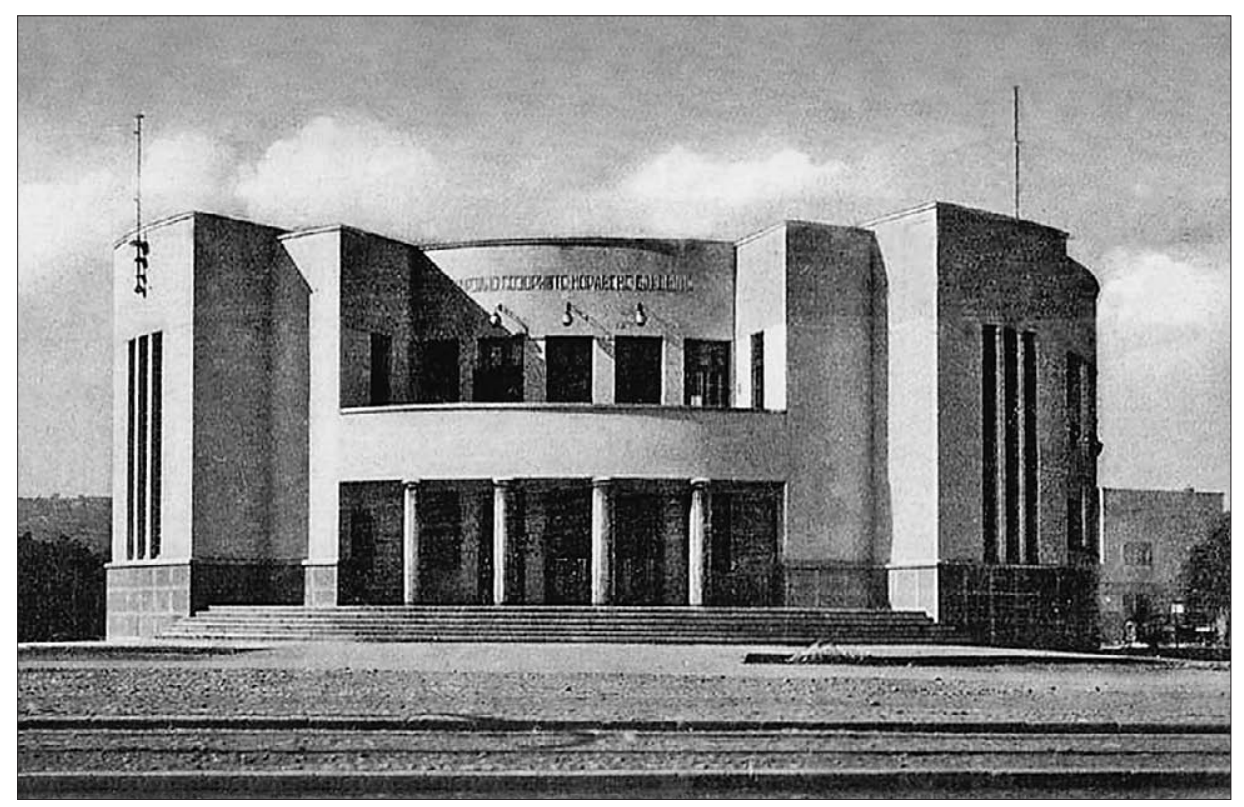

SL. 17. V.A.TATARINOV: BanOVINSKo KAZALIŠte, SINDELIĆEV TRG, NIŠ, 1938.-1939. Fig. 17 V.A. TAtARIN OV: Theatre of BANOVINA, SinĐeliCEV TRG, NIŠ, 1938-1939 


\section{LITERATURA}

BIBLIOGRAPHY

\section{IZVORI}

\section{SOURCES}

1. BAGARIĆ, M. (2011.), Arhitekt Ignjat Fischer, Meandar Media, Zagreb

2. Blagojevic, LJ. (2003.), Modernism in Serbia: The Elusive margins of Belgrade architecture 1919-1941, MIT Press [Massachusetts Institute of Technology], Cambridge (Mass.)

3. Ceranic, M. (2007.), Delatnost arhitekata Andreja Vasiljevica Papkova u Beogradu (19251951), „Nasleđe”, VIII: 71-85, Beograd

4. CVIIIC, S. (2014.), Moderna stambena arhitektura. Banjaluka 1929-1941, Zadužbina Andrejević, Beograd

5. Čanović, G. (2018.), Niško pozorište u duhu moderne, „Politika”, 11.5. (dodatak „Moja kuca”): 2, Beograd

6. Čolovic, B. (2011.), Sakralna baśtina dalmatinskih Srba, „Prosvjeta”, Zagreb

7. D.D. (2017.), Trajni spomenik prognane Ruskinje, „Budilnik RS”, 14.8., Bijeljina

8. DuRdevic, M. (1998.-1999.), Prilog proucavanju delatnosti arhitekte Valerija Vladimirovica Stasevskog u Beogradu, „Godišnjak grada Beograda”, XLV-XLVI: 151-171, Beograd

9. Durøević, M. (2005.), Arhitekt Andrej Vasiljevic Papkov, „Godišnjak grada Beograda”, LII: 297309, Beograd

10. IVAnovska Deskova, A.; Deskov, V.; IvanovSKI, J. (2018.), Skopje modernismus 1945-1990, in: Architektur im Mazedonischen context [ed. Stiller, A.], Mury Salzmann, Wien

11. Jahontov, A.; Prosen, M. (2013.), Stvaralaśtvo arhitekte Nikolaja Vasiljeviča Vasiljeva i njegov beogradski opus (maj 1921 - februar 1923), „Nasleđe”, XIV: 115-133, Beograd

12. Jovanovic, M. (2006.), Ruska emigracija na Balkanu (1920-1940), Čigoja, Beograd

13. KadIJEvic, A. (1990.), Život i delo arhitekte Dragiše Brašovana (1887-1965), „Godišnjak grada Beograda", XXXVII: 141-173, Beograd

14. Kadijevic, A. (1998.), Rad arhitekata Julijana Djupona i Vsevoloda Tatarinova u jugoistočnoj Srbiji, „Leskovački zbornik”, XXXVIII: 137-142, Leskovac

15. Kadijević, A.; Maskareli, D. (2004.), O arhitekturi Genciceve kuce, „Nasleđe”, V:135-143, Beograd

16. KadiJevic, A. (2012.), Hrvatski opus arhitekte Momira Korunovica (1883-1969) u svetlu dokumenata iz njegove porodične zaostavštine, „Ljetopis Prosvjete", 17: 322-339, Zagreb

17. KadıJevic, A. (2017.a), Arhitekti emigranti iz Rusije i hrvatska arhitektura 20. stoljeca, „Prostor", 25 (2/54/): 358-371, Zagreb, https://doi. org/10.31522/p.25.2(54).13

18. KadIJeVIC, A. (2017.b), Newer Architecture from Modernization and Destruction to Distor- ted Representation, in: Artistic Heritage of the Serbian People in Kosovo and Metochia [eds. Vojvodić, D.; MARKović, M.], Srpska akademija nauka i umetnosti: 340-349, Belgrade

19. Keković, A.; Čemerikić, Z. (2006.), Moderna Niša 1920-1941, Društvo arhitekata Niša, Niš

20. Konstantinovski, G. (2001.), Graditelite vo Makedonija XVIII-XX vek, Tabernakul, Skopje

21. Коsıк, V.I. (2010.), Русские краски на балканской палитре. Конец XIX - начало XXI века, PAH [Ruska akademija nauka], Moskva

22. LATInćıć, O. (2011.), Valerij Vladimirovič Stasevski (1882-?) u Beogradu. Podaci iz arhivske građe Istorijskog arhiva Beograda, „Nasleđe”, XII: 169-196, Beograd

23. LATInćıć, O. (2015.), Prilozi biografijama ruskih arhitekata - graditelja Beograda, „Nasleđe”, XVI: 147-160, Beograd

24. LeKo, D.M. (1926.), Nova zgrada Ministarstva poljoprivrede i voda i Ministarstva suma i rudnika, „Tehnički list”, 13-14: 193-202, Zagreb

25. LISOVSKI V.G.; GACHOT, R. (2011.), Nikolai Vasilev. Ot moderna $k$ modernizmu, Kolo, Sankt Peterburg

26. Manevic, Z. (1979.), Pojava moderne arhitekture u Srbiji, doktorska disertacija, Filozofski fakultet, Beograd

27. MARKovic, S.V. (1939.), Imenik diplomiranih inżenjera i arhitekata na Tehničkom fakultetu Univerziteta u Beogradu, Tehnički fakultet, Beograd

28. Martinović, U. (1974.), Moderna Beograda, Naučna knjiga, Beograd

29. Milovanović, M. (1994.), Andrej Vasiljević Pap kov, u: Rusi bez Rusije. Srpski Rusi [ur. BranKovıc, Z.]: 266-272, Dunaj, Beograd

30. Milovanović, M. (2004.a), Porazni zaborav, „Vračarski glasnik”, 51: 13, Beograd

31. Milovanović, M. (2004.b), Ukus najvišeg reda, "Vračarski glasnik”, 52: 13, Beograd

32. Milovanovic, M. (2004.c), Secanje na proślost, „Vračarski glasnik”, 53: 13, Beograd

33. Obad ŚCITARocI, M. (1993.), Modaliteti zaśtite obnove ljecilisnog perivoja u Lipiku, „Prostor”, 1 (2-4): 213-221, Zagreb

34. PIPLovic, S. (2008.), Izgradnja Splita izmedu svjetskih ratova, Društvo arhitekata Splita, Druśtvo prijatelja kulturne baštine u Splitu, Split

35. Puškadija-Ribkin, T. (2006.), Emigranti iz Rusije u kulturnom i znanstvenom żivotu Zagreba, Prosvjeta, Zagreb

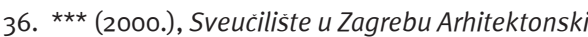
fakultet 1919/1920.-1999/2000. Osamdeset godina izobrazbe arhitekata u Hrvatskoj [ur. OBAD ŚCITAROCI, M.], Sveučilište u Zagrebu, Arhitektonski fakultet, Zagreb
INTERNETSKI IZVORI

INTERNET SOURCES

1. http://beogradskonasledje.rs/wp-content/uploads/2012/09/8/6_milica_ceranic.pdf

2. http://www.mgb.org.rs/images/godisnjaci/GodisnjakXLV-XLVI/150-171GodisnjakXLV-XLVl1998 -99.pdf

3. http://www.mgb.org.rs/images/godisnjaci/GodisnjakLII/GodisnjakLVII-296-312.pdf

4. http://beogradskonasledje.rs/wp-content/uploads/2014/01/Nasledje14/7-aleksandar-j-milan -prosen.pdf

5. http://www.mgb.org.rs/images/godisnjaci/19 90-XXXVII/141-173Godisnjak\%2ograda\%20Beograda\%201990.pdf

6. http://beogradskonasledje.rs/wp-content/uploads/2013/nasledje5/9-a-kadijevic-d-maskareli.pdf

7. https://hrcak.srce.hr/index.php?show=clanak \&id_clanak_jezik $=283543$

8. http://beogradskonasledje.rs/wp-content/uploads/2012/06/o9-olga-latincic.pdf

9. http://beogradskonasledje.rs/wp-content/uploads/2015/12/12_N16_olga_latincic.pdf

10. https://hrcak.srce.hr/index.php?show=clanak \&id_clanak_jezik=48731

\section{IZVORI ILUSTRACIJA}

\section{ILLUSTRATION SOURCES}

SL. 1. Foto: autor, 2016.

SL. 2. www.limanblogcrew.wordpress.com/2018/ 01/21/

SL. 3. www.aukcije.hr

SL. 4. Razglednica, zbirka M. Jurišica, Beograd

St. 5. www.beogradskonasledje.rs

SL. 6. Repozitorij MUO, Zagreb

SL. 7. Zbirka autora

SL. 8. www.eparhija-dalmatinska.hr

St. 9. Zbirka autora

SL. 10. www.skycrapercity

SL. 11. www.croinfo.net/zanimljivosti2/8970-ruska -pravoslavna-crkva-u-crikvenici

SL. 12. www.skycrapercity

SL. 13. www.facebook.com/1492765354286671/ photos/pcb.

SL. 14. m.facebook.com/permalink.php?story_fbid $=1541136949461702 \& \mathrm{id}=100006962354659$

SL. 15. Zbirka autora

SL. 16. www.niskevesti.rs

St. 17. Razglednica, zbirka autora 


\title{
SAŽETAK
}

\author{
SUMMARY
}

\section{PROFESSIONAL WORK OF RUSSIAN IMMIGRANT ARCHITECTS in Croatia And Yugoslavia (1920-1980)}

The professional work of Russian immigrant architects in Croatia can be looked upon from three historical perspectives: 1 ) the buildings designed by the architects who lived and worked in Croatia; 2) the buildings in Croatia designed by the architects coming from other parts of Yugoslavia; 3 ) the buildings designed by the architects who had graduated in Zagreb and then went to work abroad. The first group encompasses the architects who left indelible trace in Croatian architecture between the two World Wars and partly in the post-war socialist period. Their work was presented in the journal "Prostor" by the end of 2017. Within the second group of architects were some prolific authors who worked in Croatia for a shorter period of time. This article focuses on the third group of architects who completed their professional academic education at the Faculty of Architecture in Zagreb and then went to work abroad.

Among the architects in the second group, Nikolaj Vasiljevic Vasiljev (1875-1958) stands out as the leader of the Baltic Secession. During his short stay in Belgrade (between May 1921 and February 1923) he gained recognition in Croatia with his design of the City Savings Bank building on Ban Jelaciic square in Zagreb that won the second award at the 1921 competition. Yet, the working drawings and project supervision were entrusted to Ignjat Fischer, an experienced architect in the field. Andrej Vasiljevič Papkov (1891-1972) gained public recognition in Croatia for his design of two buildings: Josip Hrabovski House, a Modernist two-storey residential building at 25 , Vinogradska st. in Zagreb (1932) and the villa of Milan Savic at 13, Marije Terezije st. in Lipik (1932-1935), inspired by Mannerist role models. Devoid of functionalist features of the "new architecture", his two-storey building is closer to a moderate type of modern architecture practiced in Belgrade than to Zagrebstyle architecture characterized by strict adherence to International Modernism.

The villa, owned by the West-slavonian and Belgrade-based photographer Milan Savic (18831954), was built between 1932 and 1935 in Lipik (today at the address: 13 Marije Terezije st.). Unlike the two-storey row house of Josip Hrabovski, this villa features Neo-classicist articulation of its deco- rative facades. Built up as a summer retreat, it is an architectural hommage to the well-known villa of the former Serbian minister Dorđe Gencicic. Construction of the latter started in 1927 according to Dragiša Brašovan's project. It was in Brašovan's studio that Papkov used to collaborate until the building was completed in 1929.

The obtrusive and representative two-storey villa in Lipik features ornamented facades. However, its back facade is devoid of decoration. Its rich Historicist repertoire makes it stand out among the surrounding health care and catering facilities including some residential buildings. Thematically, the villa manifests analogical eclecticism although Gencic's house was not literally imitated. While its corner facade is based on Italian models, its courtyard facade was built in the manner of English Neorenaissance. Milan Savic was actively involved in developing the program for a villa containing 23 rooms. Although originally conceived as a threestorey building, it eventually ended up as a twostorey house.

While working in Belgrade, Papkov participated in the 1930 public competition for the conceptual design of the new government offices. The first and the second awards were not given while the third one was shared between Andrej Papkov and Velimir Gavrilovic (for their project "Diamant") and Dujam Granic (for his project "Ad Palatium"). After the competition had been closed without realization, it was held again in 1937 but Papkov did not take part in it.

The Church of St Nicholas (1924-1928) in Crikvenica, designed by Viktor Zelinski (1900-1985), also deserves attention as a cultural monument and a spiritual center of Russian immigrants. Although modest in size, its architectural and religious significance is comparable to the most significant Russian religious buildings in Yugoslavia - the Church of the Holy Trinity in Tašmajdan and the Iverska chapel on the New cemetery in Belgrade and the temple of St lohn the Baptist in Bela Crkva. Among the Russian religious buildings is also Voskresenjska chapel (1928) on Mirogoj cemetery in Zagreb, built according to the project by Andrej Pavlovič Ševcov (1890-1940). It shows the characteristics of the medieval Vladimir-Suzdalj School.
The prolific civil engineer Valerij Vladimirovic Staševski built in Cetina a votive one-dome Church of Holy Salvation (1937-1940). Its harmoniously proportioned cross-shaped complex, emphasized by strong fronts and lateral gable walls, is covered by an octagonal dome reminiscent of the Serbian medieval Moravian monasteries.

The third group encompasses those architects who were professionally educated in Croatia but gained recognition abroad. Among the most prominent figures was Vsevolod Aleksandrovič Tatarinov, the architect of Banovina theatre in Niš (1937-1939). The building was conceived as a modern monumental structure with art deco elements. Others were Leonid Makšejev, Viktor Zalevski, Ivan Latišev, Leonid Tarasov, Nikolaj Volkov, Fedor Wenzler, Irina Nepokojčickaja and Mihail Vorobjov. They worked in Kosovo, Monte Negro, Macedonia, Niška Banja, Sremska Mitrovica, and Belgrade. The most prolific figure among them was Leonid Makšejev, a talented architect who designed numerous Modernist multi-storey buildings in Belgrade, Irina Nepokojčickaja, the designer of numerous memorials in Sremska Mitrovica, and Fedor Wenzler who developed numerous urban-planning projects in Macedonia and Croatia.

Research into the role of the Russian immigrant architects in Croatia should be institutionally developed and supplemented with the facts. Besides filling up the missing parts in the biographies of the two authors, emphasis should also be placed on the graduates from the Faculty of Architecture in Zagreb whose work is not covered by this article due to a lack of information: Leonid Konstantinovic Astafjev, Vsevolod Lavrov (graduated in 1926), Aleksandar Turnišev (1927), Konstantin Ostrovsk (1934), Vječeslav Burlakov, Evgenij Ivanov (1936), Dimitrij Pograničnij, Konstantin Zapasov (1937), Mihail Hlopin (1938), Mihajl Sosjevič, Aleksandar Šišlov (1939), Nikolaj Martinov, Jelena Nikoljski Kottos (1946), Anatolij Kirjakov (1949), and Vladimir Zaharovič. The same can be said for the Russian immigrant students who did not graduate. An attempt should also be made to record the Russian architects employed in municipal services in Croatia in order to assess their professional contribution.

\section{BIOGRAFIJA}

\section{BIOGRAPHY}

Dr.sC. ALEKSANDAR KADIJEVIĆ (1963.) redoviti je profesor Odjela za povijest umjetnosti Filozofskog fakulteta u Beogradu od 2006. Autor je 14 monografija o povijesti novije srpske, jugoslavenske i ruske arhitekture. Član je Akademije arhitekture Srbije i nekoliko međunarodnih stručnih organizacija. Višegodišnji je ravnatelj znanstvenih projekata i autor studijskih izlożbi o historiografskim temama. Dobitnik je nagrada „Pavle Vasic” (1997.) i „Ranko Radovic” (2006.). U časopisu „Prostor” surađuje od 2011. godine.
ALEKSANDAR KaDIJEVIĆ (1963), Ph.D., Full Professor in the Department of Art History at the Faculty of Philosophy in Belgrade, author of 14 monographs on the history of modern Serbian, Yugoslav, and Russian architecture and a member of the Serbian Academy of Architecture and other international professional associations. Over many years he has been the head of scientific research projects. He was the recipient of two awards: "Pavle Vasic" in 1997 and "Ranko Radovic" in 2006. He has been a contributor to this journal since 2011. 
